\title{
IMPLEMENTASI CORPORATE SOCIAL RESPONSIBILITY PROGRAM "POJOK BACA" PT PERTAMINA EP DALAM MEMPERTAHANKAN REPUTASI PERUSAHAAN
}

\author{
Dena Intan Widiyanti ${ }^{*}$,Margareta Manalu Lovett ${ }^{2}$ \\ ${ }^{1,2)}$ Ilmu Komunikasi, STIKOM Inter Studi Jakarta \\ Jl. Wijaya II No. 62, Jakarta Selatan \\ Email: ${ }^{1}$ denadiw22@gmail.com; ${ }^{2}$ margareta.manalu@gmail.com \\ *Penulis korespondensi
}

\begin{abstract}
ABSTRAK
Public Relations memiliki fungsi agar masyarakat dapat menghargai, mendukung, dan memberikan simpati dan penilaiannya terhadap suatu perusahaan. Penilaian perusahaan yang berdasarkan dari kepercayaan masyarakat dapat dikatakan sebagai reputasi. Salah satu tugas Public Relations yang dapat membentuk reputasi adalah dengan melakukan program Corporate Social Responsibility. Corporate Social Responsibility sebagai bentuk komitmen yang dilakukan perusahaan diharapkan mampu mempertahankan dan meningkatkan reputasi perusahaan. Pada penelitian ini, kita akan melihat salah satu program Corporate Social Responsibility PT Pertamina EP yaitu program "Pojok Baca." Tujuan penelitian ini adalah untuk mengetahui bagaimana implementasi Corporate Social Responsibility program "Pojok Baca" dalam mempertahankan reputasi perusahaan. Penelitian ini merupakan penelitian kualitatif deskriptif konstruktivis. Teknik pengumpulan data dengan melakukan wawancara, observasi, dan dokumentasi. Data yang digunakan adalah data yang diperoleh dari hasil wawancara langsung dengan penerima program Corporate Social Responsibility "Pojok Baca" di SDN Karet Kuningan 01. Hasil dari penelitian menunjukkan bahwa Corporate Social Responsibility program "Pojok Baca" dapat mempertahankan reputasi PT Pertamina EP. Hal ini ditunjukkan dari respon penerima program "Pojok Baca" sebagai informan yang semakin menganggap positif reputasi PT Pertamina EP karena bentuk komitmennya dan kepeduliannya dalam melakukan perbaikan di bidang pendidikan.
\end{abstract}

Kata kunci: Public Relations, Corporate Social Responsibility, Reputasi, PT Pertamina EP.

\begin{abstract}
Public Relations has a function to make public can appreciate, support, and give sympathy and evaluation of a company. The company's evaluation based on public trust can be said as reputation. One of the function of Public Relations that can built a reputation is to carry out a Corporate Social Responsibility program. Corporate Social Responsibility as a form of commitment made by the company is expected to be able to maintain and improve the company's reputation. In this study, one of PT Pertamina EP's Corporate Social Responsibility programs will be investigated, namely "Pojok Baca" program. The purpose of this study was to find out how the implementation of the Corporate Social Responsibility "Pojok Baca" program in maintaining the reputation of the company. This research is a descriptive qualitative. Data collection techniques by interviews, observations, and documentation. The data used are data obtained from direct interviews with recipients of the Corporate Social Responsibility "Pojok Baca" program at SDN Karet Kuningan 01. The results of the study indicate that the Corporate Social Responsibility program "Pojok Baca" can maintain the reputation of PT Pertamina EP. This is shown by the response of the recipients of the "Pojok Baca" program as informants who increasingly consider PT Pertamina EP's reputation positive because of its commitment and concern in making improvements in the field of education.
\end{abstract}

Keywords: Public Relations, Corporate Social Responsibility, Reputation, PT Pertamina.

\section{PENDAHULUAN}

Public Relations menurut Betrand R Canfield dalam (Tettie Setiyarti, 2019) memiliki fungsi agar masyarakat dapat menghargai, mendukung, memberikan simpati dan penilaiannya terhadap suatu perusahaan. Penilaian perusahaan yang berdasarkan dari kepercayaan masyarakat dapat dikatakan sebagai reputasi (Trimanah, 2012). Public Relations pada perusahaan memiliki tujuan untuk meningkatkan dan mempertahankan reputasi (Nurjaman \& Umam, 2012).

Reputasi perusahaan berasal dari nilai-nilai kepercayaan yang diberikan secara individual oleh stakeholders yang berupa pandangan atau persepsi (Wulandari \& Rasipan, 2017). Salah satu tugas Public Relations yang dapat membentuk reputasi adalah dengan melakukan program Corporate Social 
Responsibility. Dengan komunikasi, kepentingan internal dan eksternal publik dapat terhubung, terutama dalam menjalankan program Corporate Social Responsibility (Ruliana, 2014). Menurut Carrol dan Shabana dalam (Bögel, 2019) Corporate Social Responsibility bertujuan untuk mencapai perbaikan bagi masyarakat dan juga mencapai keunggulan kompetitif bagi perusahaan.

Banyaknya perusahaan yang melaksanakan program Corporate Social Responsibility menjadi tanda bahwa pelaksanaan program Corporate Social Responsibility telah berkembang di Indonesia (Darwinsyah, 2018). Hal ini terjadi dikarenakan program Corporate Social Responsibility menjadi program yang wajib dilaksanakan oleh perusahaan. Kewajiban tersebut tercantum dalam Undang-Undang (UU) No. 40 th. 2007 tentang Perseroan Terbatas pasal 74 yang menyebutkan tanggung jawab sosial dan lingkungan.

Implementasi Corporate Social Responsibility yang dilakukan perusahaan sering dianggap sebuah pencitraan atau bersifat sukarela. Terdapat tiga landasan penting yang harus dimiliki oleh perusahaan dalam melaksanakan program CSR yaitu kinerja perusahaan, kinerja ekonomi, kinerja sosial dan kinerja lingkungan, tiga landasan utama tersebut biasa disebut dengan triple- bottom line reporting. Dari ketiga aspek di atas sebuah perusahaan jika ingin going concern perusahaan harus melaksanakan program CSR dengan cara yang etis, ramah terhadap lingkungan, menjalin kerja sama dengan komunitas, dan menjadikan kegiatan CSR sebagai sebuah strategi bisnis yang pada akhirnya mendapatkan hasil yang baik dan saling menguntungkan. Ketika perusahaan melaksanakan kegiatan CSR dengan tahapan yang ada, maka perusahaan telah melakukan kegiatan CSR sesuai dengan aturan yang berlaku (Gustian, 2013).

PT Pertamina EP (Exploration \& Production), anak perusahaan dari PT Pertamina, terbentuk pada 13 September 2005, berfokus di sektor hulu minyak dan gas. Sebagai salah satu industri hulu migas yang menyokong ketahanan energi di Indonesia, PT Pertamina EP berkomitmen dalam memberikan kontribusi untuk pembangunan yang berkelanjutan dengan melaksanakan Corporate Social Responsibility yang berfokus pada 5 (lima) bidang utama yaitu pendidikan, kesehatan, ekonomi, infrastruktur dan lingkungan sebagai upaya dalam meningkatkan kualitas hidup bagi masyarakat setempat maupun masyarakat luas, serta pelestarian lingkungan sebagai kegiatan yang tidak hanya mematuhi aturan dan kebijakan yang berlaku namun lebih dari itu (Pep.pertamina.com, 2020)
Program CSR dilaksanakan mulai dari tingkat lapangan operasi (Field), tingkat regional (Asset), hingga tingkat pusat (Head Office). Pelaksanaan seluruh program CSR PT Pertamina EP menerapkan prinsip triple bottom line berupa profit, people, dan planet. Profit disini mengandung makna bahwa laba yang akan diperoleh oleh PT Pertamina EP sebagai upaya untuk tetap mempertahankan jalannya aktivitas bisnis sehingga perusahaan tetap beroperasi dan berkembang. Dalam aktivitas mencari laba, PT Pertamina EP tetap memperhatikan kelestarian alam. Planet artinya bertanggung jawab untuk menjaga dan meningkatkan kualitas lingkungan, dimana perusahaan menjaga sumber daya alam dan keseimbangan lingkungan dalam melaksanakan aktivitas bisnisnya sehingga upaya dalam pembangunan berkelanjutan dapat tercapai. People artinya bertanggung jawab secara sosial dengan berupaya memberdayakan dan meningkatkan kesejahteraan masyarakat dengan membantu mengatasi permasalahan yang ada di masyarakat.

Penelitian ini membahas program "Pojok Baca", yang merupakan salah satu program CSR PT Pertamina EP dalam bidang pendidikan. Peneliti memilih program ini untuk diteliti karena bidang pendidikan merupakan bidang yang relevan dengan peneliti.

CSR Analyst PT Pertamina EP mengungkapkan bahwa yang menjadi pertimbangan program "Pojok Baca" ini dilaksanakan adalah berdasarkan data Organisasi Pendidikan, Keilmuan, dan Budaya PBB (UNESCO) menyebutkan Indonesia berada pada urutan kedua dari bawah terkait literasi dunia dari negara-negara anggota yang disurvey, artinya minat baca yang sangat rendah. Minat baca masyarakat Indonesia sangat memprihatinkan, hanya $0,001 \%$. Artinya, dari 1,000 orang Indonesia, hanya 1 orang yang rajin membaca.

Riset lainnya bertajuk pada World's Most Literate Nations Ranked yang dilakukan oleh Central Connecticut State Univesity pada Maret 2016 lalu, Indonesia dinyatakan menduduki peringkat ke-60 dari 61 negara soal minat membaca, persis berada di bawah Thailand (59) dan di atas Bostwana (61). Padahal, dari segi penilaian infrastuktur untuk mendukung membaca, peringkat Indonesia berada di atas negara-negara Eropa.

Selain itu, pembangunan perpustakaan umum di Indonesia masih sangat lemah. Hal ini menujukkan bahwa keadaan perpustakaan di Indonesia tidak dapat dikatakan ideal karena pembangunannya yang belum 
merata. Meskipun pendapatnya itu ditujukan bagi perpustakaan umum, namun dapat menjadi gambaran bagi kita bahwa perpustakaan di negara kita masih banyak yang belum diselenggarakan sebagaimana layaknya pelayanan perpustakaan yang baik (Bkp.go. id, 2021).

Untuk menjawab permasalahan terkait rendahnya literasi dan kurangnya perpustakaan yang memadai, salah satu program yang diinisiasi adalah program "Pojok Baca". Program "Pojok Baca" Pertamina EP merupakan program CSR di bidang pendidikan dalam rangka menyediakan akses baca dan meningkatkan literasi/minat baca bagi anak-anak usia 6-15 tahun, yang dilaksanakan baik di fasilitas pendidikan (Sekolah Dasar dan Sekolah Menengah Pertama) maupun di fasilitas umum yang keseluruhannya tersebar di 23 titik lokasi sekitar wilayah kerja PT Pertamina EP.

Adapun yang menjadi tujuan dari program "Pojok Baca" antara lain:

1. Meningkatkan minat baca masyarakat dengan mendirikan Taman Bacaan di seluruh wilayah Indonesia, khususnya wilayah 3T (Tertinggal, Terdepan, Terluar);

2. Meningkatkan keterampilan dan pemberdayaan masyarakat Indonesia dengan program-program yang diintegrasikan ke dalam berbagai kegiatan dalam Taman Bacaan;

3. Menanamkan rasa semangat meraih ilmu sebanyak-banyaknya dan bersekolah setinggi-tingginya bagi anak-anak.

4. Untuk meningkatkan dan mempertahankan reputasi positif perusahaan di mata masyarakat.

Dalam mewujudkan visi "planet", CSR Analyst PT Pertamina EP mengungkapkan bahwa program "Pojok Baca" terdiri dari 300 buku yang disesuaikan dengan kebutuhan penerima manfaat (sekolah/ fasilitas umum), yang sebagian besar jenis bukunya adalah buku easy reading tentang ilmu pengetahuan terkait alam dan lingkungan, sehingga anak-anak dan siapapun yang membacanya akan dengan mudah mengaplikasikan hal-hal sederhana terkait perlindungan lingkungan di lingkungannya masing-masing. Selain itu, sebagian dari buku-buku yang disampaikan adalah buku-buku yang cetak produksinya menggunakan kertas daur ulang yang tentunya ramah lingkungan.

CSR Analyst PT Pertamina EP mengungkapkan kriteria dalam memilih sekolah yang layak mendapatkan program ini yaitu sekolah negeri yang tidak mempunyai perpustakaan, dan juga sekolah tersebut wajib berada di Wilayah 3T (Tertinggal, Terdepan, Terluar).

CSR Analyst PT Pertamina EP juga menerangkan bahwa Wilayah 3T merupakan wilayah prioritas PT Pertamina EP dalam melaksanakan program CSR. Wilayah tertinggal merupakan wilayah yang memiliki akses yang sulit untuk menuju wilayah tersebut, seperti di Tampor Paloh, Aceh Timur. Wilayah Terdepan merupakan wilayah yang berbatasan langsung dengan negara lain, seperti Nunukan, Kalimantan Utara. Wilayah Terluar merupakan wilayah terluar dari negara seperti Sabang, Kepulauan Mentawai, dan Sangihe, Pulau Rote di NTT. Sejauh ini, Program "Pojok Baca" telah dilaksanakan di Tampor Paloh - Aceh Timur, Nunukan - Kalimantan Utara, dan Bangkalan -Jawa Timur.

Sebagai bentuk kontribusi PT Pertamina EP yang berlokasi di Jakarta, maka juga dilaksanakan program "Pojok Baca" di Jakarta. Penelitian ini akan mengupas penerima program "Pojok Baca" di Jakarta, yaitu SDN Karet Kuningan 01. Walaupun SDN Karet Kuningan 01 bukan merupakan wilayah 3T, namun PT Pertamina EP memilihnya karena berlokasi dekat dengan kantor PT Pertamina EP agar dapat dengan mudah melakukan monitoring dan dianggap tidak mempunyai perpustakaan yang layak.

Berdasarkan pemaparan di atas, terdapat rumusan masalah, yakni bagaimana implementasi Corporate Social Responsibility program "Pojok Baca" PT Pertamina EP dalam mempertahankan reputasi perusahaan.

Manfaat dari penelitian ini, secara teoritis diharapkan mampu membantu memahami dalam ilmu komunikasi tentang CSR dan kaitannya dengan reputasi. Manfaat secara praktis, diharapkan bisa menjadi bahan pertimbangan bagi perusahaan untuk merencanakan kegiatan operasionalnya, serta dapat dijadikan bahan perbaikan dalam melakukan kegiatan CSR.

\section{TINJAUAN LITERATUR}

Peneliti menggunakan jurnal acuan yang berjudul "Company reputation and its influence on consumer trust in response to ongoing CSR communication" oleh (Bögel, 2019). Hasil dari penelitian tersebut menunjukkan bahwa program Corporate Social Responsibility yang dilaksanakan dapat mempertahankan reputasi perusahaan. 
Berikutnya, peneliti menggunakan jurnal dari (Ham \& Kim, 2020) yang berjudul The Effect of CSR Communication in corporate crises: Examining the role of dispositional and situational CSR skepticism in context. Hasil dari penelitian tersebut yaitu program CSR yang dilakukan dapat mengatasi krisis yang terjadi pada perusahaan.

Peneliti juga menggunakan jurnal dari (Kim, Yin, \& Lee, 2020) yang berjudul The effect of CSR on corporate image, customer citizenship behaviors, and customers' long-term relationship orientation. Hasil dari penelitian ini menujukkan bahwa program CSR yang dilakukan oleh perusahaan berpengaruh pada citra perusahaan dan juga kepercayaan konsumen dalam jangka panjang.

Penelitian yang dilakukan ini memiliki persamaan dengan penelitian-penelitian terdahulu yaitu, kesamaan dalam meneliti program Corporate Social Responsibility dalam perusahaan dan kaitannya dalam mempertahankan reputasi ataupun citra dan kepercayaan konsumen. Sedangkan perbedaan antara penelitian sebelumnya dengan penelitian ini adalah program CSR yang dilaksanakan pada perusahaan, metode yang digunakan, dan hasil akhir dari tiap penelitian.

\subsection{Public Relations}

Menurut Cutlip,Center,Broom dalam (Goi \& Yong, 2009), Public Relations merupakan fungsi dalam manajemen untuk menjaga ikatan yang menguntungkan antara perusahaan dengan masyarakat.

Webster New International Dictionary of the English, Language mengatakan jika Public Relations merupakan kegiatan yang dilaksanakan oleh suatu perusahaan yang menghasilkan dan memelihara ikatan yang berguna dengan publik tertentu (Nurjaman \& Umam, 2012).

Public Relations merupakan bagian terpenting dalam perusahaan, karena berfungsi untuk mencapai reputasi baik yang diperoleh dari kepercayaan publik (Rumanti, 2002).

\subsection{Corporate Social Responsibility}

World Businness Council on Sustainable Development mendefinisikan Corporate Social Responsibility sebagai komitmen perusahaan agar memiliki perilaku etis dan melakukan kontribusi terhadap pembangunan yang berkepanjangan (Andrini, 2018).
Dalam Indonesia Business Link, (Triyanto, 2015) terdapat lima hal dalam konsep Corporate Social Responsibility yaitu:

1. Sumber daya manusia (SDM) dan pemberdayaan masyarakat setempat dapat dikembangkan.

2. Memperkuat ekonomi

3. Keharmonisan dengan masyarakat sekitar dapat terjaga

4. Mendukung good governance

5. Kelestarian lingkungan dapat terjaga

Dalam konsep Corporate Social Responsibility versi Indonesia Business Link menekankan bahwa aspek ekonomi dan sosial dalam perusahaan harus tercapai dengan seimbang.

\subsection{Manfaat Corporate Social Responsibility}

Menurut United States Based For Social Responsibility dalam (Reni Erliani, 2019), manfaat dari Corporate Social Responsibility yaitu:

1. Program Corporate Social Responsibility yang telah dilakukan memberikan pengaruh dan dapat meningkatkan dan mempertahankan reputasi perusahaan.

2. Dengan program Corporate Social Responsibility memberikan pengaruh untuk meningkatkan loyalitas, karena pelanggan beranggapan kualitas yang diberikan juga selaras dengan tujuan perusahaan.

3. Dengan program Corporate Social Responsibility, anggaran untuk biaya promosi dapat dikurangi. Perusahaan akan dikenal saat menjalankan program Coporate Social Responsibility. Dengan hal ini, program Corporate Social Responsibility bisa menjadi alternatif sebagai program promosi.

Dalam penerapan program Corporate Social Responsibility akan memberikan dampak antara masyarakat dengan perusahaan dan berpengaruh pada reputasi yang menguntungkan bagi perusahaan (Reni Erliani, 2019).

\subsection{Impelementasi Corporate Social Responsibility}

Tahapan implementasi Corporate Social Responsibility tersebut menurut (Anatan, 2009), yaitu:

1. Langkah pertama yaitu dengan mengamati masalah yang terjadi di lingkungan sekitar perusahaan dan memberikan jawaban dari permasalahan atau solusi untuk mengatasi masalah tersebut.

2. Langkah kedua yaitu perusahaan mempersiapkan dana dan menyalurkan dana tersebut untuk melaksanakan langkah pertama. 
3. Langkah ketiga yaitu melakukan monitoring kegiatan melalui kunjungan langsung.

4. Langkah keempat yaitu perusahaan melakukan evaluasi dengan rutin dan menjadikan hasil evaluasi menjadi panduan dalam melaksanakan program lainnya.

\subsection{Reputasi}

Dawling, dalam Butterick (Ruliana, 2014) menyebutkan reputasi perusahaan sebagai hasil penilaian dari pandangan masyarakat.

Wartick dalam (Reni Erliani, 2019) mendefinisikan reputasi selaku cerminan atas tanggapan dari tiap- tiap stakeholders tentang seberapa baik perusahaan dalam membagikan respons dalam permintaan serta harapan dari khalayak yang dapat terpenuhi.

Penilaian pada perusahaan bergantung pada setiap kegiatan yang dilakukan oleh perusahaan. Maka dari itu, reputasi harus dikelola dengan baik agar perusahaan selalu didukung dan mendapatkan kepercayaan dari masyarakat (Atriana, 2017).

\subsection{Indikator Reputasi}

Indikator yang ada pada reputasi ialah (Tarigan, 2014):

1. Dengan nama baik yang selalu dipertahankan oleh perusahaan, persepsi stakeholders dapat digunakan untuk meningkatkan pemasaran perusahaan. Nama baik merupakan indikator yang sangat penting untuk dijaga. Nama baik akan memberi pengaruh bagi konsumen dalam memberikan kepercayaannya.

2. Perusahaan harus menjadi perusahaan yang kuat dan memiliki nilai lebih, agar memiliki keunggulan yang tidak dimiliki perusahaan lain.

3. Dengan dikenal luas oleh khalayak, menampilkan sejauh mana perusahaan telah berhasil mengenalkan produknya.

4. Memiliki ingatan yang baik pada perusahaan. Nama perusahaan yang mudah diingat akan berpengaruh bagi khalayak untuk dapat menemukan perusahaan tersebut.

\section{Kerangka Penelitian}

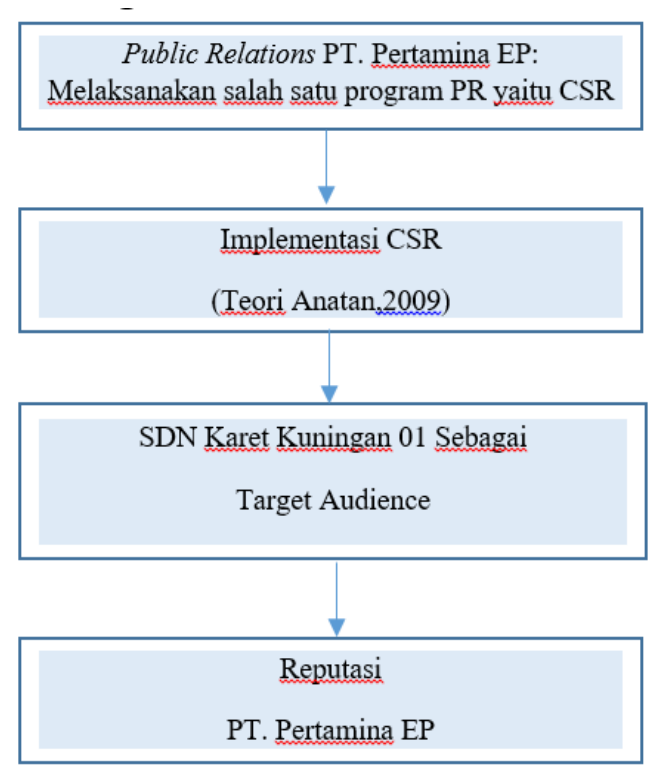

Gambar 1. Kerangka Penelitian

Kerangka penelitian dalam penelitian ini menggunakan teori Implementasi CSR (Anatan, 2009). Anatan mengungkapkan bahwa untuk menggapai tujuan yang diharapkan yaitu bertahannya reputasi pada perusahaan, maka pelaksanaan Corporate Social Responsibility harus berjalan sesuai dengan prosedur dan tahapan yang ada.

\section{METODE}

Penelitian kualitatif deskriptif digunakan dalam penelitian ini karena peneliti ingin mencari fakta akurat yang memberikan hasil terpercaya (Tanzeh \& Arikunto, 2004). Pendekatan konstruktivis dipilih dalam penelitian ini karena setiap orang memiliki pemahaman yang berbeda walaupun berada dalam kejadian yang sama. Berdasarkan dari latar belakang setiap orang yang berbeda, akan digunakan untuk menanggapi suatu peristiwa (Butsi, 2019).

Pengumpulan data dilakukan dengan wawancara mendalam (in-depth interview), observasi, dan dokumentasi. Pertanyaan yang diajukan bertujuan untuk mendapatkan kedalaman informasi (Ruslan, 2013). 
Wawancara dilakukan dengan seseorang yang mengetahui informasi tentang permasalahan yang akan diteliti atau yang biasa disebut dengan informan (Ruslan, 2013). Teknik purposive sampling digunakan dalam menentukan informan yang sesuai dengan kriteria yang ada, yaitu yang terlibat secara langsung dalam proses implementasi CSR program "Pojok Baca.". Informan yang sesuai dengan kriteria tersebut adalah:

1. Kepala Sekolah (Informan 1)

2. Guru Sekolah penerima program "Pojok Baca" (Informan 2)

3. Orang tua siswa (Informan 3)

4. CSR Analyst PT Pertamina EP (Informan 4)

Mereka dipilih menjadi informan karena dianggap paling memahami masalah yang diteliti. Murid-murid SDN Karet Kuningan 01 tidak terpilih menjadi informan karena dengan keterbatasan umur dianggap belum bisa menjelaskan masalah dan runtutan peristiwa secara jelas dan lengkap. Setelah data terkumpul, peneliti melakukan proses teknik analisis data dengan coding (Alhogbi, 2017). Trianggulasi data atau keabsahan data penelitian pada metode kualitatif melalui beberapa cara seperti credibility, transferability, dependability, dan juga confirmability (Ruslan, 2013). Pada penelitian ini, hasil dari trianggulasi data dapat dilihat dari hasil wawancara dan hasil observasi dengan berbagai informan sehingga mendapatkan berbagai perspektif dan memperoleh data yang mendekati kebenaran.

\section{HASIL DAN PEMBAHASAN}

\subsection{Implementasi CSR Program "Pojok Baca" di SDN Karet Kuningan 01}

\section{Tahap 1: Mengamati masalah yang terjadi}

Tahap pertama implementasi CSR yaitu mengamati masalah yang terjadi dan memberikan solusi terhadap masalah tersebut. Hasil riset yang dilakukan oleh CSR Analyst PT Pertamina EP menujukkan bahwa minat baca di Indonesia rendah, sehingga PT Pertamina EP terpanggil untuk ikut berkontribusi dalam kegiatan CSR-nya untuk memberikan solusi dari masalah ini. Dan solusi tepat untuk mengatasi permasalahan tersebut adalah dengan melaksanakan program "Pojok Baca".

Program "Pojok Baca" merupakan program CSR PT Pertamina EP di bidang pendidikan dalam rangka menyediakan akses baca dan meningkatkan literasi/ minat baca bagi anak-anak usia 6-15 tahun, yang dilaksanakan baik di fasilitas pendidikan maupun di fasilitas umum yang keseluruhannya tersebar di 23 titik lokasi sekitar wilayah kerja PT Pertamina EP. PT Pertamina EP mengatakan bahwa "Pojok Baca" diharapkan memiliki andil yang besar terhadap pembentukan dan pengembangan sumber daya manusia yang berkualitas yang nantinya akan berpengaruh terhadap pembangunan berkelanjutan bangsa Indonesia.

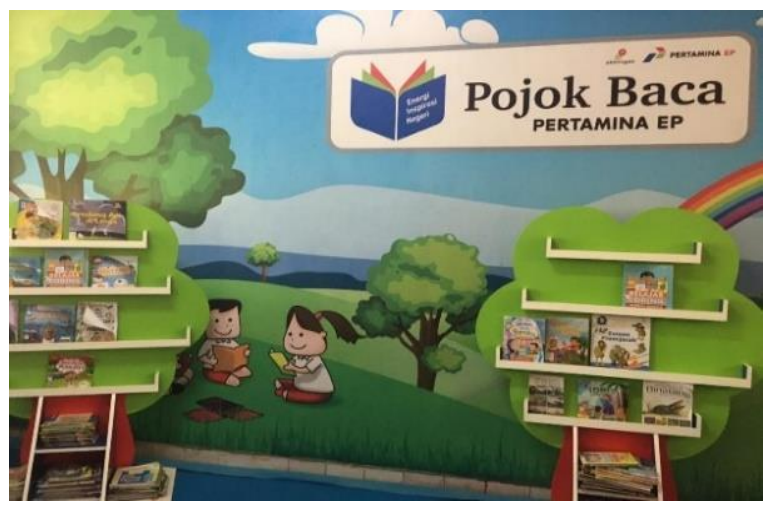

Gambar 2. Perpustakaan Pojok Baca

Pada tahap awal, sebelum memberikan proposal kerja sama program "Pojok Baca", PT Pertamina EP telah meninjau sekolah terdekat dari kantor PT Pertamina EP. Sekolah terdekat menjadi kriteria utama karena PT Pertamina EP berharap bisa selalu memantau dan melaksanakan monitoring terhadap sekolah tersebut. Sekolah terdekat yang menjadi pilihan utama untuk ditinjau yaitu SDN Karet Kuningan 01. Dan dari hasil tinjauan tersebut, SDN Karet Kuningan 01 terpilih untuk diberikan program "Pojok Baca". SDN Karet Kuningan 01 terpilih menjadi penerima program "Pojok Baca" karena kondisi perpustakaan di SDN Karet Kuningan 01 yang kurang layak untuk digunakan para siswa. Hal ini juga yang memotivasi PT Pertamina EP untuk memberikan bantuan program "Pojok Baca".

Setelah dipilihnya SDN Karet Kuningan 01 sebagai penerima program "Pojok Baca", pihak PT Pertamina EP mendatangi kembali SDN Karet Kuningan 01 untuk memberikan proposal kerja sama tentang program "Pojok Baca". Proposal tersebut berisikan tentang tujuan program "Pojok Baca" dan juga detail tentang bantuan yang akan diberikan. Dalam proposal tersebut, disebutkan pula bahwa PT Pertamina EP bekerja sama dengan Balai Pustaka sebagai penyedia buku untuk program "Pojok Baca". PT Pertamina EP bekerja sama dengan Balai Pustaka karena merupakan perusahaan BUMN yang memiliki tujuan yang sama untuk membangun generasi negeri yang 
sadar dan peduli terhadap literasi. Balai Pustaka akan memberikan buku-buku pengetahuan umum untuk anak-anak sebanyak 300 buku serta audiobook berupa 10 headphones yang berisikan cerita dongeng dalam versi bahasa Indonesia dan bahasa Inggris. Selain memberikan buku dan audiobook, PT Pertamina EP juga ingin melakukan renovasi terhadap perpustakaan di SDN Karet Kuningan 01.

Proposal yang diberikan PT Pertamina EP disambut baik oleh pihak SDN Karet Kuningan 01. Hal ini dibenarkan oleh informan yang merupakan Kepala Sekolah dan juga Guru SDN Karet Kuningan 01 yang merasa senang dan menyetujui program "Pojok Baca" karena memiliki tujuan yang sama yaitu meningkatkan minat baca para siswa, mendukung gerakan pemerintah daerah tentang gerakan literasi, dan juga karena kondisi perpustakaan yang kurang layak dan tidak memiliki buku-buku bacaan edisi terbaru.

Informan 1 dan 2 mengungkapkan bahwa pada tahun 2005, SDN Karet Kuningan 01 merupakan SDN percontohan pada fasilitas perpustakaan. Namun seiring dengan berjalannya waktu, perpustakaan tersebut tidak terawat dengan baik. Karena itu, SDN Karet Kuningan 01 menerima program "Pojok Baca", agar perpustakaannya dapat kembali menjadi perpustakaan percontohan.

Proposal disetujui oleh pihak SDN Karet Kuningan 01 tanpa memakan waktu yang lama. Hal itu digambarkan oleh informan 1, "Mereka datang, memberikan proposal, dan minta izin, lalu karena kami sudah terlalu senang jadi langsung di proses dan melakukan persiapan." Proses persiapan dan perbaikan fasilitas perpustakaan dilakukan selama kurang lebih 2 minggu. Dalam 2 minggu, tim CSR Analyst PT Pertamina EP menyiapkan buku-buku dan audiobook yang akan diletakkan di perpustakaan "Pojok Baca".

Renovasi perpustakaan dilakukan dengan mendekorasi ulang perpustakaan seperti perbaikan pada cat dinding, pemberian alas duduk berupa karpet, penggantian lampu dan juga dilakukan pemasangan AC.

Dalam mengajukan proposal kerja sama program "Pojok Baca", CSR Analyst PT Pertamina EP mengungkapkan, terdapat perbedaan saat memberikan sosialisasi di wilayah kota besar dan wilayah daerah terpencil. Jika di daerah terpencil, sosialisasi yang diberikan mengenai program CSR yang akan diberikan sering mengalami kesusahan karena masyarakat kadang menganggap buruk niat baik PT Pertamina EP.
CSR Analyst PT Pertamina EP mengungkapkan terdapat beberapa hambatan disaat PT Pertamina EP melaksanakan program "Pojok Baca" di daerah terpencil di Indonesia, yaitu:

1. Distribusi buku-buku serta kelengkapan lainnya ke seluruh wilayah Indonesia, khususnya wilayah 3T (Tertinggal, Terdepan, Terluar) yang kadang sulit dijangkau bahkan oleh ekspedisi besar sekalipun.

2. Masih kurangnya minat baca siswa pada awal pembentukan pojok baca.

3. Motivasi yang kurang dari beberapa siswa terkait pentingnya menambah ilmu dan wawasan dari buku.

4. Perusahaan diangggap punya misi tertentu terkait operasi (contoh: perusahaan mengambil hati masyarakat melalui sekolah karena adanya issue rencana pengeboran migas di lokasi tersebut).

CSR Analyst PT Pertamina EP mengungkapkan untuk mengatasi hambatan-hambatan yang terjadi pada saat pelaksanaan perlu dilaksanakannya langkah-langkah berikut:

1. Menggunakan fasilitas transportasi internal perusahaan untuk mendistribusikan ke wilayahwilayah 3T.

2. Melakukan penguatan dan sosialiasi melalui guruguru terkait menariknya buku-buku yang diberikan.

3. Meningkatkan motivasi dengan adanya Pertamina EP Mengajar ke sekolah-sekolah yang dimaksud, sehingga anak-anak menjadi tertarik untuk membaca lebih banyak buku-buku yang diberikan.

4. Mensosialisasikan kepada masyarakat sekitar bahwa kegiatan ini murni bentuk CSR perusahaan.

\section{Tahap 2: Menyiapkan dan menyalurkan dana}

Tahap kedua dalam proses implementasi CSR adalah mempersiapkan dana yang akan disalurkan untuk melaksanakan tahap pertama. Dalam tahap ini, PT Pertamina EP tidak pernah memberikan dana secara langsung untuk program-program pemberdayaannya kepada masyarakat.

Hal ini juga di benarkan oleh Informan 1 dan 2 bahwa penyaluran dana CSR yang diberikan PT Pertamina EP untuk program "Pojok Baca" ini tidak berupa uang, melainkan berupa barang-barang yang dibutuhkan dan juga renovasi pada fasilitas. Informan 1 dan 2 mengatakan bahwa mereka harus melapor apa saja hal yang diperlukan untuk pembangunan fasilitas "Pojok Baca" ini dan PT Pertamina EP akan 
menyediakannya. Renovasi yang dilakukan seperti renovasi ruangan perpustakaan, penempatan rak-rak buku, dan juga pemasangan AC.

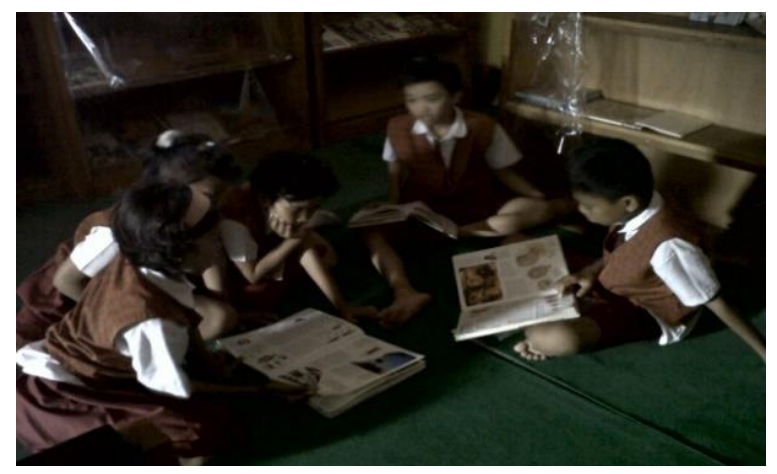

Gambar 3. Kondisi Awal Perpustakaan

Di awal perbaikan fasilitas ini pihak sekolah SDN Karet Kuningan 01 melalukukan renovasi dengan mendekorasi ulang dinding perpustakaan, lalu mengisi ruangan perpustakaan dengan karpet sebagai alas duduk para siswa, melakukan penggantian lampu, dan selanjutnya pengisian rak-rak untuk menaruh buku-buku. Pada tahap akhir, dilakukan pemasangan $\mathrm{AC}$ dan rak-rak buku yang sudah ada disi dengan buku-buku dari PT Pertamina EP yang bekerja sama dengan Balai Pustaka. Buku yang diberikan sebanyak 300 buku, dengan jenis yang berbeda seperti buku pengetahuan, buku dongeng, dan juga buku kumpulan cerita anak yang tersedia dalam bahasa Inggris, dan juga diberikan audiobook berupa 10 headphones yang berisikan cerita dongeng dalam bahasa Indonesia dan bahasa Inggris. Pihak SDN Karet Kuningan 01 mengungakapkan kisaran biaya untuk melakukan renovasi perpustakaan adalah sekitar 5-10 juta rupiah.

Setelah proses perbaikan fasilitas perpustakaan rampung, dilaksanakan acara peresmian program "Pojok Baca" pada 25 Oktober 2019, pembukaan acara peresmian berlangsung meriah dengan pertunjukan tari, pertunjukkan wayang, dan penampilan paduan suara oleh siswa, sambutan kepala sekolah, sambutan sekretaris camat Setiabudi, sambutan oleh direktur PT Pertamina EP, dilanjutkan dengan pengenalan program "Pojok Baca" oleh pihak PT Pertamina EP, dan juga pembagian snack untuk para siswa. Semua persiapan acara peresmian program "Pojok Baca" dibantu oleh PT Pertamina EP dalam segi pembelian barang-barang yang dibutuhkan dalam renovasi perpustakaan dan juga pembelian snack untuk seluruh siswa.

Pada peresmian program "Pojok Baca", PT Pertamina EP bekerja sama dengan Balai Pustaka dan memberikan 300 buku dan audiobook. Informan 1 dan 2 mengatakan bahwa buku-buku yang diberikan oleh PT Pertamina EP merupakan buku-buku yang ramah lingkungan dan dapat didaur ulang. Semua informan mengungkapkan rasa kagum dan senang karena selain para siswa mendapatkan manfaat pengetahuan baru dari buku yang diberikan, dapat juga membantu melestarikan alam karena mendapatkan buku-buku yang ramah lingkungan.

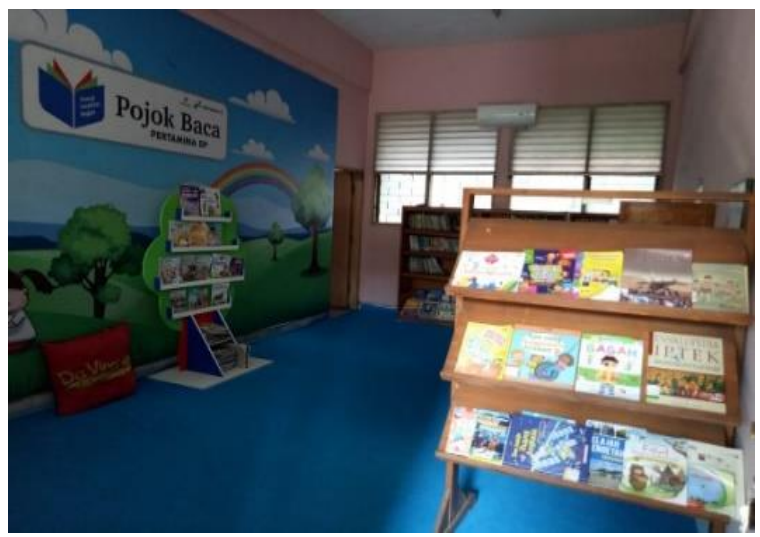

Gambar 4. Kondisi Perpustakan Setelah dilakukan Renovasi

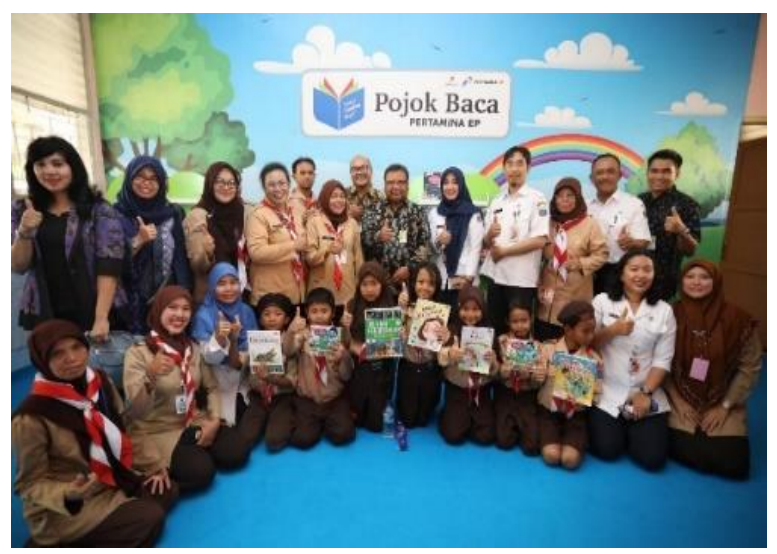

Gambar 5. Peresmian Program Pojok Baca

Peresmian ini dihadiri oleh seluruh siswa dan guruguru SDN Karet Kuningan 01. Peresmian ini juga dihadiri oleh berbagai staff PT Pertamina EP seperti, CSR staff, CSR analyst, assistant manager, manager sampai vice president, dan diresmikan langsung oleh Nanang Abdul Manaf yang merupakan Presiden Direktur PT Pertamina EP. Acara ini juga dihadiri oleh sekretaris camat Setiabudi. Dalam peresmian acara ini diliput oleh media internal PT Pertamina EP dan berita tentang peresmian program "Pojok Baca" ini diunggah di website resmi PT Pertamina EP. Dan ketika acara tersebut berjalan semua informan menyebutkan sangat terkesan karena acara berjalan lancar dan tidak terjadi kendala. 


\section{Tahap 3: Melaksanakan monitoring}

Tahap implementasi CSR yang ketiga adalah melaksanakan monitoring. Pada tahap ini CSR Analyst PT Pertamina EP melaksanakan monitoring secara daring mengingat 3 bulan setelah peresmian program "Pojok Baca" ini terjadi Pandemi Covid-19.

Informan 1 dan 2 mengatakan bahwa monitoring dilakukan oleh pihak PT Pertamina EP dengan menanyakan kondisi fasilitas "Pojok Baca". Informan 1 dan 2 mengungkapkan bahwa fasilitas "Pojok Baca" tetap dirawat dan dibersihkan secara berkala. Para petugas sekolah yang datang ke sekolah di masa Pandemi Covid-19 ini tetap melaksanakan kewajibannya untuk merawat dan membersihkan fasilitas "Pojok Baca". Fasilitas "Pojok Baca" dilakukan pengecekkan dan dibersihkan selama 2 kali dalam seminggu secara rutin.

Informan 1 dan 2 mengatakan bahwa sebelum dan sesudah terjadi pandemi, program "Pojok Baca" selalu dirawat dan dijaga kebersihannya. Informan 1 dan 2 mengungkapkan salah satu perawatan buku dengan memberikan sampul dan juga diberi tanda warna yang berbeda untuk setiap kategori buku. Hal ini dilakukan agar kerapian pada buku-buku tetap terjaga. Setiap buku selalu sesuai dengan kategorinya dan tidak tercecer di tempat lain.

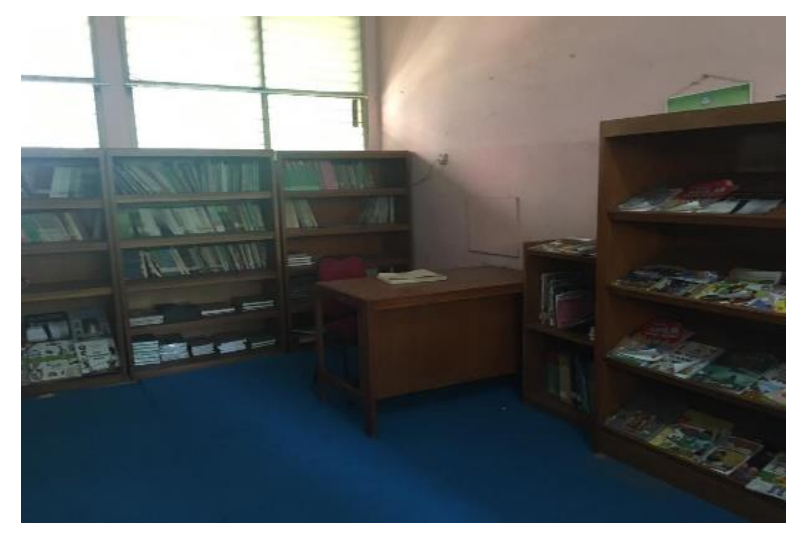

Gambar 6. Pojok Baca di masa pandemi

Informan 1 dan 2 mengungkapkan yang bertanggung jawab atas peminjaman buku adalah para wali kelas yang bertugas sesuai dengan jadwal kunjungan perpustakaan yang telah ditetapkan. Para wali kelas wajib dengan teliti memeriksa kartu peminjaman buku para siswa dan memahami mengenai bukubuku yang dipinjam oleh para siswanya. Apabila ada buku yang tidak dikembalikan ataupun rusak, siswa yang meminjam harus bertanggung jawab dengan mengganti buku tersebut.
Adapun syarat dan ketentuan agar dapat membaca di perpustakaan "Pojok Baca" yang diungkapkan oleh informan 2, adalah para siswa diwajibkan untuk membaca sesuai jadwal yang sudah ditetapkan, dan juga para siswa hanya boleh meminjam 1 buku. Hal ini diterapkan agar para siswa dapat menyelesaikan dan memahami dengan baik buku yang dibaca. Setelah selesai membaca buku yang dipinjam, baru diperbolehkan untuk meminjam buku yang lainnya. Namun, buku hanya bisa dibaca di area sekolah dan tidak bisa dibawa pulang, agar para guru tetap bisa mengontrol dan menghindari terjadinya kerusakan pada buku apabila buku dibawa pulang.

Semua informan mengatakan bahwa sebelum adanya pandemi, program "Pojok Baca" berjalan dengan baik, dan tidak ditemukannya hambatan. Hambatan justru terjadi ketika Pandemi Covid-19 melanda, para siswa yang diharuskan sekolah dari rumah tidak dapat menggunakan fasilitas "Pojok Baca" ini. Namun, informan berharap walaupun terjadi pandemi, bisa dilaksanakan program sejenis dengan kemudahan untuk diakses di masa pandemi ini yang juga dapat meningkatkan minat baca siswa. Hal ini digambarkan oleh informan 1, "Kami berharap anak-anak walaupun di rumah aja masih suka membaca ya, jadi tetep ada aktivitas yang bermanfaat, semoga ke depannya bisa dipikirkan lagi oleh PT Pertamina untuk kasih program sejenis di masa covid ini".

\section{Tahap 4: Melakukan Evaluasi}

Tahap implementasi CSR yang terakhir adalah melakukan evaluasi. Pada tahap ini, semua informan mengatakan evaluasi juga belum bisa dilakukan oleh PT Pertamina EP dikarenakan kondisi Pandemi Covid-19 yang masih terjadi. Hal ini juga dibenarkan CSR Analyst PT Pertamina EP bahwa evaluasi belum bisa dilaksanakan mengingat Pandemi Covid-19 yang masih terjadi di Indonesia.

Namun, semua informan mengatakan bahwa manfaat terbesar yang dirasakan setelah program "Pojok Baca" diresmikan yaitu meningkatnya minat baca para siswa. Hal ini dibuktikan dengan rasa semangat para siswa yang selalu ingin membaca di perpustakaan "Pojok Baca" ini. Minat baca para siswa meningkat karena buku-buku yang diberikan memiliki banyak variasi, dan isi cerita yang menarik. Hal ini juga dibuktikan dengan antusias yang tinggi para siswa saat jadwal mereka tiba untuk membaca di perpustakaan "Pojok Baca". Informan 1 juga menggambarkan para siswa sangat terkesan saat mendapat giliran untuk membaca, "Minat baca siswa yang 
pasti meningkat ya, para siswa juga semangat untuk menyambut giliran atau jadwal mereka membaca di perpustakaan Pojok Baca."

Para informan berharap bisa kembali terjalin kerja sama dengan PT Pertamina EP yang tentunya dalam bidang pendidikan dan lingkungan, seperti penanaman pohon, pengenalan profesi, dan juga pelatihan komputer. Hal ini digambarkan oleh informan 2, "Semoga di masa pandemi ini, PT Pertamina EP juga bisa memberi kerja samanya dalam bidang pendidikan ataupun lingkungan, seperti pelajaran penanaman pohon ataupun pengenalan profesi yang mungkin bisa dilakukan secara online."

\subsection{Penilaian Informan terhadap Reputasi Perusahaan}

Berdasarkan penelitian terhadap indikator pada reputasi, terdapat hasil sebagai berikut, SDN Karet Kuningan 01 sebagai penerima program "Pojok Baca" memberikan penilaian positif terhadap PT Pertamina EP. PT Pertamina EP menjadi jawaban top of mind semua informan ketika ditanya tentang perusahaan minyak dan gas. Hal ini menujukkan bahwa informan memiliki ingatan yang baik pada PT Pertamina EP. Seperti yang dideskripsikan oleh informan 1, "Yang ada di pikiran saya kalau minyak dan gas, nah udah pasti yang terbenak itu ya Pertamina, yang ada di otak saya."

Penilaian positif terhadap perusahaan PT Pertamina EP juga didasari kontribusi PT Pertamina EP dalam kepeduliannya di bidang pendidikan. Hal ini menujukkan bahwa PT Pertamina EP mendapatkan nama baik dari informan.

Yang menjadikan PT Pertamina menjadi perusahaan yang dikenal luas, dikarenakan produk PT Pertamina tersebar di seluruh Indonesia. Hal ini digambarkan oleh informan 1, "Karena kita lihat dimana-mana, simbolnya dan tulisannya itu Pertamina. Apalagi produknya juga banyak dimana-mana, jadi teringat pada Pertamina." Semua informan juga mengungkapkan bahwa PT Pertamina merupakan perusahaan yang dikenal luas oleh masyarakat dikarenakan produknya yang digunakan dalam kehidupan seharihari dan kemudahan produk untuk didapatkan. Dalam kehidupan sehari-hari, semua informan menggunakan produk PT Pertamina.

Semua informan mengatakan bahwa tidak mengetahui dan memahami mengenai perusahaan kompetitor yang berada dalam bidang minyak dan gas. Semua informan hanya mengetahui nama perusahaan kompetitor seperti Shell, namun kurang mengetahui produk dan juga program-program yang diberikan perusahaan kompetitor. Hal ini menujukkan PT Pertamina merupakan perusahaan yang kuat dan lebih unggul dari perusahaan kompetitor.

Semua informan juga memberikan penilaian positif terhadap PT Pertamina EP sebelum dan sesudah program "Pojok Baca" diberikan. Penilaian informan terhadap reputasi PT Pertamina EP menjadi semakin baik, terutama karena mereka terkesan pada kepedulian dan komitmen PT Pertamina EP di bidang pendidikan. CSR Analyst PT Pertamina EP juga membenarkan bahwa reputasi PT Pertamina EP bertahan secara positif sejak dilaksanakannya program ini. Informan 2 juga mengatakan dengan ada atau tidaknya program "Pojok Baca" ini, mereka tetap menggunakan produk PT Pertamina EP karena merupakan produk yang dibutuhkan sehari-hari.

\section{SIMPULAN}

Berdasarkan hasil penelitian Implementasi Corporate Social Responsibility Program "Pojok Baca" PT Pertamina EP dalam Mempertahankan Reputasi Perusahaan yang dilakukan oleh peneliti maka dapat diperoleh kesimpulan bahwa program "Pojok Baca" dapat mempertahankan reputasi perusahaan PT Pertamina EP. Hal ini dapat dirasakan dari penilaian positif yang diberikan semua informan penerima "Pojok Baca" menyatakan bahwa mereka lebih tertarik untuk menggunakan produk dari Pertamina karena di mata mereka Pertamina telah memberikan sumbangsih atau kebaikan bagi bangsa lewat program "Pojok Baca".

Dalam penelitian ini dijelaskan tentang tahapan implementasi Corporate Social Responsibility. Apabila perusahaan melaksanakan program Corporate Social Responsibility sesuai dengan tahapan yang ada, maka tujuan dari perusahaan tersebut dapat tercapai. Hal itu dibuktikan dengan program "Pojok Baca" yang berjalan sesuai dengan tahapan yang ada dan dapat mempertahankan reputasi PT Pertamina EP.

Program CSR sudah berjalan cukup baik, dibuktikan dengan hasil reputasi yang bertahan di mata para penerima program "Pojok Baca". Namun terdapat saran yaitu diperlukan inovasi dari perusahaan untuk dapat melaksanakan program lain seperti penanaman pohon, pengenalan profesi, dan juga pelatihan komputer dan juga mengeluarkan program "Pojok Baca" versi digital. Hal ini dilakukan agar di masa pandemi ini para siswa tetap bisa menggunakan fasilitas "Pojok Baca" dan juga mencapai tujuan utama 
program ini yaitu meningkatkan minat baca para siswa. "Pojok Baca" via digital juga diharapkan bisa memenuhi selera generasi para centenials yang lebih menyukai dunia digital. Diharapkan PT Pertamina EP juga dapat membuat press release mengenai keberlangsungan program "Pojok Baca" di masa pandemi ini.

\section{DAFTAR PUSTAKA}

Alhogbi, B. G. (2017). 済無No Title No Title. Journal of Chemical Information and Modeling, 53(9), 21-25. Retrieved from http://www.elsevier.com/locate/scp

Anatan, L. (2009). Corporate Social Responsibility ( CSR): Tinjauan Teoritis dan Praktik di Indonesia. Jurnal Manajemen Maranatha Christian University, 8(2), 66-77. Retrieved from majour.maranatha.edu/index.php/jurnalmanajemen/article/view/220

Andrini, S. (2018). Peran Csr Awards Dalam Котиnikasi Antar Budya.

Atriana, N. (2017). pengaruh reputasi dan inovasi produk tabungan terhadap keputusan menabung pada Bank Syariah di Bandar Lampung (Studi pada mahasiswa perbankan Syari'ah Fakultas Ekonomi dan Bisnis Islam UIN Raden Intan Lampung. 15-68.

Bkp.go.id. (2021). Perpustakaan di Indonesia. Retrieved from www.bkp.go.id

Bögel, P. M. (2019). Company reputation and its influence on consumer trust in response to ongoing CSR communication. Journal of Marketing Communications, 25(2), 115-136. https://doi.org/10.1080/13527266.2016.1166146

Butsi, F. I. (2019). Memahami Pendekatan Positivis, Konstruktivis Dan Kritis Dalam Metode Penelitian Komunikasi. Psikologi Perkembangan, 2 (October 2013), 1-224. Retrieved from http://ejurnal.stikpmedan.ac.id

Darwinsyah, M. (2018). Analisis Pengaruh Komunikasi CSR Melalui Media Sosial Terhadap Reputasi Perusahaan. Inter Komunika: Jurnal Komunikasi, 3 No. 1. Retrieved from https://journal.interstudi.edu/index.php/InterKo munika/article/view/43/pdf

Goi, C. L., \& Yong, K. H. (2009). Contribution of Public Relations (PR) to Corporate Social Responsibility (CSR): A Review on Malaysia Perspective. International Journal of Marketing Studies, 1(2), 46-49. https://doi.org/10.5539/ ijms.v1n2p46.

Gustian, R. (2013). Implementasi Corporate Social Responsibility (Csr) Di Bank Nagari Skripsi. Journal of Chemical Information and Modeling, 53(9), 1689-1699.
Ham, C. D., \& Kim, J. (2020). The effects of CSR communication in corporate crises: Examining the role of dispositional and situational CSR skepticism in context. Public Relations Review, 46(2). https://doi.org/10.1016/j.pubrev.2019.05. 013

Kim, M., Yin, X., \& Lee, G. (2020). The effect of CSR on corporate image, customer citizenship behaviors, and customers' long-term relationship orientation. International Journal of Hospitality Management, 88. https://doi.org/10.1016/ j.ijhm.2020.102520

Nurjaman, K., \& Umam, K. (2012). Komunikasi \& Public Relations (1st ed.). Bandung: CV PUSTAKA SETIA.

Pep.pertamina.com. (2020). Pertamina EP. Retrieved from http://pep.pertamina.com/visi-misi

Reni Erliani. (2019). Implementasi Corporate Social Resoponsibility (CSR) dalam Mempertahankan Reputasi Perusahaan Berdasarkan Perspektif Syari'ah (Studi Kasus PT Bank Muamalat Indonesia KCP Curup). IAIN Curup.

Ruliana, P. (2014). Komunikasi Organisasi (Teori dan Studi Kasus) (1st ed.; T. P. Penyuntingan, Ed.). Depok: PT RAJAGRAFINDO PUSAKA

Rumanti, M. A. (2002). Dasar-Dasar Public Relations: Teori dan Praktik. Jakarta: PT. Grasindo.

Ruslan, R. (2013). Metode Penelitian Public Relations dan Komunikasi (1st ed.). Jakarta: PT RAJAGRAFINDO PERSADA.

Tanzeh, A., \& Arikunto, S. (2004). Metode Penelitian Metode Penelitian. Metode Penelitian, 22-34.

Tarigan, R. M. (2014). Roy Marthin Tarigan, Pengaruh Citra Merek dan Reputasi Perusahaan Terhadap Keputusan Pembelian, (Jurnal Program Studi Strata-1 Manajemen Ekstensi Departemen Manajemen Fakultas Ekonomi dan Bisnis Universitas Sumatera Utara, 2014) 1. $15-68$.

Tettie Setiyarti, M. R. Al. (2019). Riset Ekonomi Manajemen. Jurnal Untidar, 2(2), 93-101. Retrieved from https://www.neliti.com/id/publications/288823/analisis-marketing-mix-dalammendorong-keputusan-pembelian-susu-bubukbalita-di

Trimanah. (2012). Reputasi Dalam Kerangka Kerja Public Relations. Jurnal Ilmiah Komunikasi, 3(1), 92-102. Retrieved from http://jurnal.unissula.ac.id/index.php/makna/article/view/117

Triyanto, D. (2015). Pelaksanaan Corporate Social Responsibility (CSR) Di Bidang Pendidikan PT. Hino Motors Sales Indonesia (PT. HMSI). In Biomass Chem Eng (Vol. 49).

Wulandari, A., \& Rasipan, R. (2017). Peran Reputasi Dalam Membangun Kepercayaan Konsumen. Jurnal Manajemen Kewirausahaan, 14(2), 121-132. 